OPEN ACCESS

Edited by:

Tiegang Fang

North Carolina State University,

United States

Reviewed by:

Haifeng Liu,

Tianjin University, China

Buyu Wang,

Tsinghua University, China

*Correspondence:

Christine Mounaïm-Rousselle christine.rousselle@univ-orleans.fr

Specialty section:

This article was submitted to Engine and Automotive Engineering,

a section of the journal

Frontiers in Mechanical Engineering

Received: 12 May 2020

Accepted: 20 July 2020

Published: 08 September 2020

Citation:

Mounaïm-Rousselle $C$ and Brequigny P (2020) Ammonia as Fuel for Low-Carbon Spark-Ignition

Engines of Tomorrow's Passenger

Cars. Front. Mech. Eng. 6:70

doi: 10.3389/fmech.2020.00070

\section{Ammonia as Fuel for Low-Carbon Spark-Ignition Engines of Tomorrow's Passenger Cars}

\author{
Christine Mounaïm-Rousselle* and Pierre Brequigny \\ Univ. Orléans, INSA-CVL, PRISME, EA 4229, Orléans, France
}

Faced with the problem of reducing greenhouse gas emissions and transitioning toward a greater use of renewable energies, ammonia, as an energy carrier, is increasingly seen as a potential "green" fuel for transportation, in particular marine applications. However, its combustion characteristics (high minimum ignition energy and auto-ignition temperature, low combustion speed in comparison to usual hydrocarbon fuels) are drawbacks that have so far limited its use. Due to the evolution of different pollutant standards for road transportation, spark-ignition engines and thus the combustion process itself have been subjected to many changes over the last 20 years (e.g., gasoline direct injection, downsizing). The objective of this article is to discuss the potential of ammonia as a fuel for spark-ignition engines, thanks to the studies carried out so far and to point out directions for future work.

Keywords: ammonia, spark-ignition engine, efficiency, pollutants, future

\section{INTRODUCTION}

According to the International Energy Agency (IEA) ${ }^{1}$, "green" hydrogen will play a key role in the world's transition to a sustainable energy future as it is one of the most promising and clean energy carriers, for both transportation and power generation (Valera-Medina et al., 2018; Wijayanta et al., 2019). However, even using the best available technologies, its density is too low for it to be easily transported and stored with acceptable safety and at a reasonable cost. Instead, another suitable hydrogen carbon-free vector can be considered, namely, ammonia, or "chemically energized" water, which can be used not only as a hydrogen carrier but also as a fuel. In a comparative review of different potential hydrogen storage methods, energy efficiency and cost (Wijayanta et al., 2019), $\mathrm{NH}_{3}$ appeared to be the cheapest one with a high energy efficiency when direct use is considered, especially in comparison to liquid or high-pressure compressed hydrogen (Koike et al., 2012; Zhou et al., 2019).

Recently, studies based on system analysis concluded that "green" ammonia has a real potential to be considered as a Power-to-Fuel for our energy future and that the greenhouse gas emissions from an ammonia-driven vehicle could be less than one third of gasoline- or diesel-driven vehicles (Angeles et al., 2018; Bicer and Dincer, 2018).

\footnotetext{
${ }^{1}$ https://www.iea.org/reports/the-future-of-hydrogen
} 
TABLE 1 | Main studies and literature results on the use of ammonia in SI engines.

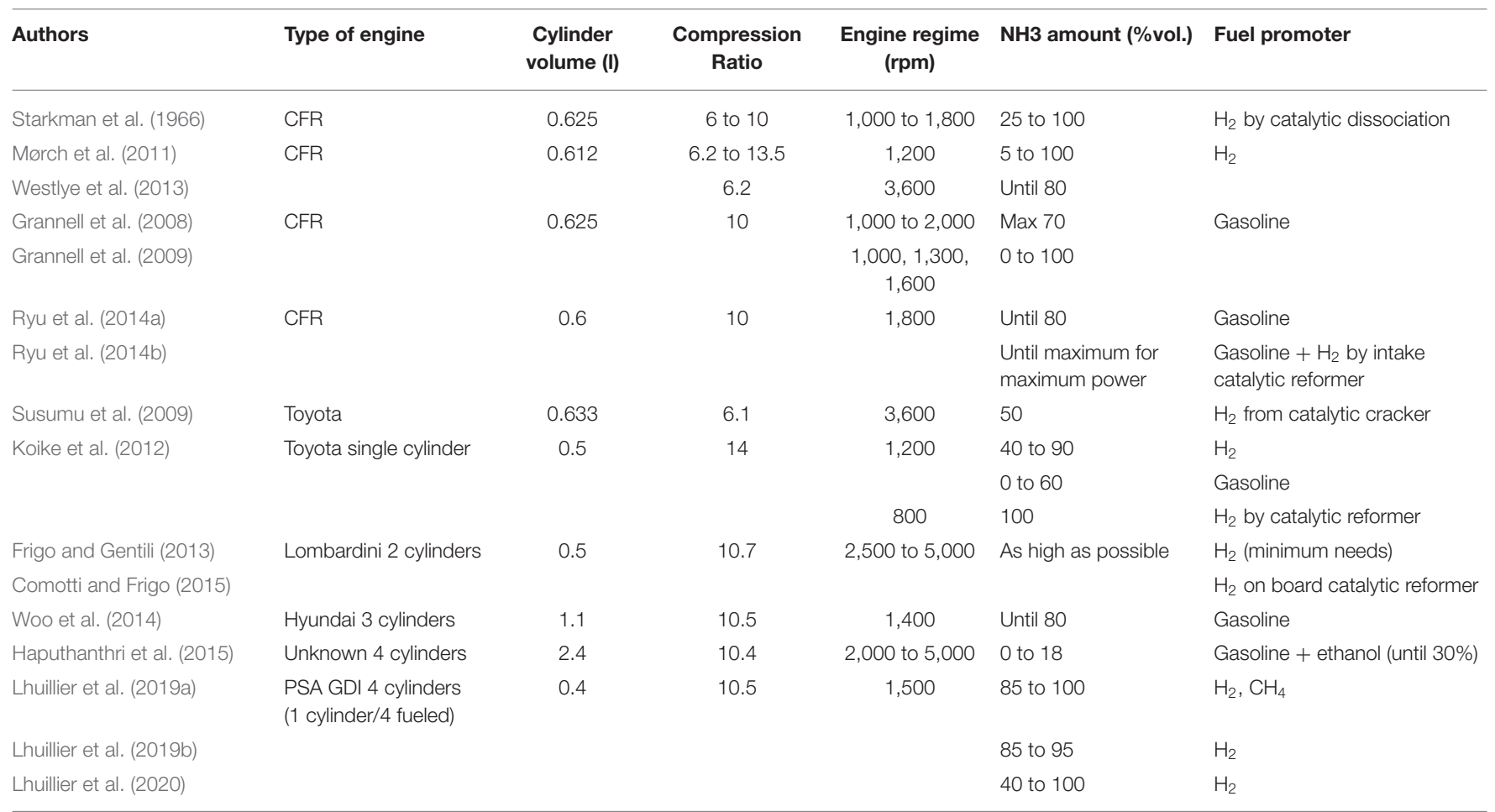

Even though at the moment there is no transport fleet operating with ammonia as fuel, the use of ammonia as an alternative to fossil fuels for transportation vehicles was considered during the twentieth century. The first well-known example is the case of the bus fleet operated in Belgium during World War II due to the limited availability of diesel fuel (Koch, 1949). The first dual-fuel engine was invented: coal gas, composed of $50 \% \mathrm{H}_{2}$, was directly injected into the combustion chamber filled with ammonia. In the mid-60s, several studies (Cornelius et al., 1965; Garabedian and Johnson, 1965; Gray et al., 1966; Starkman et al., 1966, 1967; Pearsall and Garabedian, 1967; Sawyer et al., 1968) focused on the possibility of using ammonia as fuel in thermal engines, first providing recommendations about the compatibility of ammonia with engineering materials and lubricants, due to its corrosiveness to copper, copper alloys, nickel, and even some plastics.

The two classical engine architectures were considered in these studies, i.e., spark-ignition (SI) and compression ignition (CI). Even if for the moment, most projects concern CI engines (Dimitriou and Javaid, 2020), the low auto-ignition ability of ammonia suggests that it would be more suitable to use ammonia as a fuel in the SI mode. Its energy content for one quantity of air introduced for a stoichiometric mixture is higher than that of gasoline, but fuel consumption is double in the case of neat ammonia. Its narrow flammability limits and low flame speed can induce incomplete combustion in SI engines, but ignition could be favored with $\mathrm{H}_{2}$ or a gasoline blend and the in-cylinder temperature can be increased by a higher compression ratio or supercharged conditions without any risk of knocking.
Table 1 summarizes the conditions of all the experimental studies performed with ammonia in SI engines. While some studies were conducted in CFR engines with a regular compression ratio (CR) around 6:1, most of them increased the CR to around 10:1, a value closer to that of current vehicle engines. Only two studies (Mørch et al., 2011; Koike et al., 2012) explored higher CRs up to 14:1. While the best (and carbonfree) promoter is hydrogen, which has a very high combustion velocity and wide flammability range, some studies focused on ammonia/gasoline blends for greater fuel flexibility (Grannell et al., 2008, 2009; Susumu et al., 2009; Mørch et al., 2011; Koike et al., 2012; Ryu et al., 2014a,b; Haputhanthri et al., 2015). Globally, similar performances were obtained with the introduction of ammonia in the fuel up to a certain percentage, but after a threshold level, engine performances were improved, especially at higher engine speeds and full load.

In the following sections, the main results obtained from previous studies are summarized and discussed according to three aspects: operating constraints and global performance results, ammonia injection strategies, and pollutant emissions.

\section{GLOBAL PERFORMANCE}

\section{Ammonia Only Operation}

It is striking to note that only a few studies have explored the possibility of fueling an engine with neat ammonia. To promote this concept, several technological solutions have been proposed such as plasma jet igniters or a spark plug array (Susumu et al., 2009). The use of pure ammonia was found to be possible 
with sufficiently low cyclic variation, mainly at full load (Koike et al., 2012). Moreover, even with a 14:1 CR, under boosted conditions (up to 2.2 bar), no knocking occurred at $800 \mathrm{rpm}$ with a stoichiometric air/ $\mathrm{NH}_{3}$ mixture. Recently, these results were confirmed in another current modern SI engine (Lhuillier et al., 2019a,b). Apart from Susumu et al.'s study, the ignition system used for all studies has been the original standard with an optimized ignition advance; the higher the part of $\mathrm{NH} 3$, the earlier the phasing is compared to TDC (up to 45-50 CAD before TDC in the case of pure NH3).

\section{Ammonia and $\mathrm{H}_{2}$}

A comprehensive database, ranging from the leanest air/fuel mixtures to the richest one as a function of $\mathrm{H}_{2}$ content, is provided by Mørch et al. (2011). Ammonia storage by a metal complex and the possibility of desorbing the complex by means of the heat available at the exhaust as a function of $\mathrm{H}_{2}$ content and equivalence ratio was first considered. The indicated efficiency and the load decreased as a function of $\mathrm{H}_{2}$ increase, due to higher wall heat losses as underlined in Lhuillier et al. (2020). The highest efficiency was reached for a lean equivalence ratio, but the highest load was obtained for a stoichiometric, or even slightly rich, mixture, which was also confirmed for boosted conditions in a current engine (Lhuillier et al., 2020). It was found that $5 \% \mathrm{vol} . \mathrm{H}_{2}$ was enough to guarantee engine stability with a higher efficiency than gasoline operation. However, the compression ratio has to be increased to maintain the same load as with gasoline or the intake pressure needs to be increased, as in Lhuillier et al. (2019a), to maintain a similar load to that of methane in order to limit the $\mathrm{H}_{2}$ needs. The minimum $\mathrm{H}_{2}$ required as a function of engine regime was also evaluated, and the study concluded that in average, at half and full load 11-12 and 6-7\%vol. of $\mathrm{H}_{2}$, respectively, were required (Frigo and Gentili, 2013). As a consequence, however, the output power obtained with "optimized minimum $\mathrm{H}_{2}$ " was found to be between 10 and $25 \%$ less than with gasoline depending on engine speed and load.

By means of auto-thermal catalyst converters, the addition of hydrogen on demand and in situ can be done, avoiding the risks and costs associated with storing and distributing hydrogen. (Comotti and Frigo, 2015), and (Koike et al., 2012), explored the possibility to provide sufficient hydrogen to certify stable combustion at any load. However, it seems that a very large amount of $\mathrm{H}_{2}$ is needed at idle speed, which is impossible to reach with an on-board ammonia auto-thermal cracker, but only Frigo and Gentili (2013) mentioned it.

\section{INJECTION SPECIFICITIES}

Most studies were based on the injection of gaseous ammonia inside the intake port by means of dedicated injectors or LPG types, due to the physical properties of ammonia, i.e., in the gaseous phase at a pressure below 10 bar and $25^{\circ} \mathrm{C}$. Other injection strategies can be selected, however: gaseous phase directly inside the combustion chamber (Ryu et al., 2014a), liquid injection in the intake port (Starkman et al., 1966) or in the combustion chamber (Sasaki and Sarlashkar, 2012), or an ammonia/ethanol/gasoline emulsion (Haputhanthri et al., 2015). Ryu et al. (2014a) studied the impact of injection strategy for direct gaseous ammonia injection inside the combustion chamber as a function of injection duration and phasing: the total engine power increased as the ammonia injection timing was advanced as did the injection duration, as a function of the load. This makes it possible to achieve better fuel efficiency with ammonia as a substitute for gasoline in a conventional SI engine with a reasonable idling performance, unlike indirect injection, which results in a load decrease of $30 \%$ in the worst case, thus involving the need for a higher CR, as pointed out by Mørch et al. (2011). Due to the high latent heat of vaporization of ammonia, the injection of liquid ammonia reduces the temperature and vaporization occurs easily below an ambient pressure of 9 bar at $25^{\circ} \mathrm{C}$ ambient gas temperature (or 20 bar at $50^{\circ} \mathrm{C}$ ). When the liquid injection takes place in the intake port, a better engine filling is obtained, inducing an increase of load between 12 and 15\% (Koike et al., 2012). It was also mentioned that the turbulence generated by the ammonia jet is enhanced and favors the mixing process. An injector concept for direct liquid injection was developed by Sasaki and Sarlashkar (2012) with the possibility of simultaneously injecting hydrogen. Even if engine output power may be higher with direct liquid injection of ammonia inside the cylinder, the decrease of in-cylinder temperature could have a drastic consequence on the combustion process (Starkman et al., 1966). However, no data are available on direct liquid injection into the cylinder and there is a general lack of accurate data, making it difficult to evaluate the best ammonia injection strategy.

TABLE 2 | Summary of main tendencies for Ammonia/ $\mathrm{H}_{2}$ in $\mathrm{Sl}$ engines: performances and emissions.

\section{Combustion and performances in SI engines}

\begin{tabular}{lll}
\hline $\begin{array}{l}\text { Minimum } \mathrm{H}_{\mathbf{2}} \text { for } \\
\text { combustion stability }\end{array}$ & Efficiency & Output energy \\
\hline $\begin{array}{l}\text { Between } 5 \text { and } 10 \% \text { in } \\
\text { vol }\end{array}$ & Higher for ER $>=1$ & $\begin{array}{l}\text { Less than gasoline } \\
\text { at low and partial } \\
\text { load }\end{array}$ \\
$\begin{array}{l}\text { Amount needed } \\
\text { decreases with load } \\
\text { increase (full load: } 0 \%)\end{array}$ & Higher than gasoline & $\begin{array}{l}\text { Increase with CR } \\
\text { or boosted } \\
\text { slight effect of engine } \\
\text { speed }\end{array}$ \\
\hline
\end{tabular}

Pollutant Emissions before any after treatment device

\begin{tabular}{lllll}
\hline & $\begin{array}{l}\text { ER decrease } \\
\text { (lean) }\end{array}$ & $\begin{array}{l}\text { ER increase } \\
\text { (rich) }\end{array}$ & $\begin{array}{l}\mathbf{H}_{2} \\
\text { increase }\end{array}$ & Load \\
\hline $\begin{array}{llll}\mathrm{NOx} \\
(\mathrm{ppm})\end{array}$ & ++ maximum & -- & + & $\begin{array}{l}\text { Slight } \\
\text { increase but } \\
\text { no universal } \\
\text { trend }\end{array}$ \\
& $>$ gasoline & & & $\begin{array}{l}\text { No universal } \\
\text { trend }\end{array}$
\end{tabular}




\section{Exhaust Pollutants}

Grannell et al. (2009) and Westlye et al. (2013) concluded that NOx emissions with neat ammonia are equal to or less than with gasoline for stoichiometric or slightly rich fuel/air mixtures. With the optimized minimum quantity of $\mathrm{H}_{2}$, NOx emissions could be only half those of gasoline (Comotti and Frigo, 2015), but for lean mixtures, NOx emissions are higher with a peak at an equivalence ratio around $0.7 / 0.8$ (up to $8,000 \mathrm{ppm}$ in wet gas volume). A second peak was even observed for leaner mixtures as a function of ignition timing, no doubt due to the ammonia kinetics (Westlye et al., 2013). Several studies (Ryu et al., 2014b; Woo et al., 2014; Comotti and Frigo, 2015) found that NOx emissions (in ppm) increase with load, as with classical fuels, but that brake-specific NOx emissions decrease due to the high fuel economy at high load (Ryu et al., 2014b). In contrast, no significant effect of the charge was noted (Lhuillier et al., 2019a,b). Overall, increasing $\mathrm{H}_{2}$ increases $\mathrm{NO}_{\mathrm{x}}$ emissions, due to the impact on the adiabatic temperature. The proportion of $\mathrm{NO}_{2}$ in total $\mathrm{NO}_{\mathrm{x}}$ was always found to be lower than that of $\mathrm{NO}$, with some ammonia dependency. Lastly, very low levels of $\mathrm{N}_{2} \mathrm{O}$ emissions (below $100 \mathrm{ppm}$ ) were also found in these studies, without a significant effect of the quantity of $\mathrm{NH}_{3}$. This indicates that $\mathrm{N}_{2} \mathrm{O}$, the unique contributor to global warming from $\mathrm{NH}_{3}$ combustion, will have a low impact even if its global warming potential over 100 years is 310 times higher than its $\mathrm{CO}_{2}$ equivalent mass. The other main pollutant in the case of $\mathrm{NH}_{3}$ combustion remains the unburnt $\mathrm{NH}_{3}$ itself, with a high level for rich air/fuel mixtures (up to $2 \%$ vol.wet, Lhuillier et al., 2019a). Unburnt $\mathrm{NH}_{3}$ emissions were found to be constant even for lean mixtures and without any effect of combustion phasing, mainly due to crevice trapping, due to high CR (Westlye et al., 2013). Post-catalyst pollutant measurements showed that a standard three-way catalyst remains efficient even with ammonia blends but only for stoichiometric or $0.2 \%$ rich air/fuel mixture (Grannell et al., 2009). The positive impact of an ammonia catalyst cracker was demonstrated on $\mathrm{NH}_{3}$ emissions, due to $\mathrm{NH}_{3}$ dissociation itself, but its effect on NOx emissions was inconclusive and depended on the $\mathrm{NH}_{3}$ quantity at the intake (Ryu et al., 2014b). Lastly, from exhaust temperature values displayed in Westlye et al. (2013) and Lhuillier et al. (2020), a selective catalytic reduction system or other thermal system could be considered to limit NOx emissions but would require an additional $\mathrm{NH}_{3}$ trap to limit $\mathrm{NH}_{3}$ slip. It has to be noted that unique measurements of $\mathrm{H}_{2}$ at the exhaust were performed in

\section{REFERENCES}

Angeles, D. A., Tan, R. R., Aviso, K. B., Are, K. R. A. G., and Razon, L. F. (2018). Fuzzy optimization of the automotive ammonia fuel cycle. J. Clean. Prod. 186, 877-882. doi: 10.1016/j.jclepro.2018.03.143

Bicer, Y., and Dincer, I. (2018). Life cycle assessment of ammonia utilization in city transportation and power generation. J. Clean. Prod. 170, 1594-1601. doi: 10.1016/j.jclepro.2017.09.243

Comotti, M., and Frigo, S. (2015). Hydrogen generation system for ammonia-hydrogen fuelled internal combustion engines. Int. J. Hydrogen Energy 40, 10673-10686. doi: 10.1016/j.ijhydene.2015. 06.080 our previous studies (Lhuillier et al., 2019a,b): high $\mathrm{H}_{2}$ emissions for rich mixtures can be linked to some $\mathrm{NH}_{3}$ auto-thermal conversions inside the cylinder itself.

\section{CONCLUSION AND RECOMMENDATIONS}

The major trends from the referenced studies are summarized in Table 2. Most of them were conducted in CFR engines, which are not representative of current SI engine architectures, or on laboratory single-cylinder engine benches with stable initial thermal conditions. Recent results performed in current SI combustion chambers confirmed that a compression ratio around 10:1 could be sufficient to burn ammonia with small quantities of $\mathrm{H}_{2}$ (around 5-10\%vol.) or even without $\mathrm{H}_{2}$ in "full" load, for future hybrid vehicles or range extender systems. By considering ammonia in all-thermal powertrain vehicles, a variable compression ratio or boosted intake pressure would undoubtedly have the advantage of allowing easier operation with ammonia with an optimized minimum quantity of $\mathrm{H}_{2}$ produced onboard. More studies on multi-cylinder engine benches are needed to improve whole systems especially during cold-start conditions. Moreover, further dedicated comparative studies on the different injection technologies and strategies are required before considering ammonia as a vehicle fuel. Finally, the issue of pollutant emissions is not trivial and requires in-depth studies before being able to propose optimized solutions according to the best operating mode to deal with the problem of NOx and/or $\mathrm{NH}_{3}$ or even $\mathrm{H}_{2}$. As pointed out by Angeles et al. (2018), any optimization of the automotive ammonia fuel cycle suffers from "the limited data available on the performance of ammoniafueled vehicles."

\section{DATA AVAILABILITY STATEMENT}

The original contributions presented in the study are included in the article/supplementary material, further inquiries can be directed to the corresponding author/s.

\section{AUTHOR CONTRIBUTIONS}

CM-R: leader of several projects on Ammonia as fuel in Prisme laboratory. PB: in charge of the experiments on ammonia as fuel. All authors: contributed to the article and approved the submitted version. 
Grannell, S., Assanis, D., Gillespie, D., and Bohac, S. (2009). "Exhaust emissions from a stoichiometric, ammonia and gasoline dual fueled spark ignition engine," in Proceedings of the ASME Internal Combustion Engine Divivision 2009. Spring Technical Conference (Milwaukee, WI).

Grannell, S. M., Assanis, D. N., Bohac, S. V., and Gillespie, D. E. (2008). The fuel mix limits and efficiency of a stoichiometric, ammonia, and gasoline dual fueled spark ignition engine. J. Eng. Gas Turbines Power 130:042802. doi: 10.1115/1. 2898837

Gray, J. T., Dimitroff, E., Meckel, N. T., and Quillian, R. D. (1966). “Ammonia fuel - engine compatibility and combustion," SAE Technical Paper.

Haputhanthri, S. O., Maxwell, T. T., Fleming, J., and Austin, C. (2015). Ammonia and gasoline fuel blends for spark ignited internal combustion engines. J. Energy Resour. Technol. 137:062201. doi: 10.1115/1.4030443

Koch, E. (1949). Ammonia as a fuel for motor buses. J. Inst. Pet. 31, 21-32.

Koike, M., Miyagawa, H., Suzuoki, T., and Ogasawara, K. (2012). "Ammonia as a hydrogen energy carrier and its application to internal combustion engines," in Sustainable Vehicle Technologies, eds G. Warwickshire (Woodhead Publishing), 61-70.

Lhuillier, C., Brequigny, P., Contino, F., and Mounaïm-Rousselle, C. (2020). Experimental study on ammonia/hydrogen/air combustion in spark ignition engine conditions. Fuel 269:117448. doi: 10.1016/j.fuel.2020. 117448

Lhuillier, C., Brequigny, P., Contino, F., and Rousselle, C. (2019a). Combustion Characteristics of Ammonia in a Modern Spark-Ignition Engine. SAE Technical Paper 2019-24-0237. doi: 10.4271/2019-24-0237

Lhuillier, C., Brequigny, P., Contino, F., and Rousselle, C. (2019b). Performance and Emissions of an Ammonia-Fueled SI Engine with Hydrogen Enrichment. SAE Technical Paper 2019-24-0137. doi: 10.4271/201924-0137

Mørch, C. S., Bjerre, A., Gøttrup, M. P., Sorenson, S. C., and Schramm, J. (2011). Ammonia/hydrogen mixtures in an SI-engine: engine performance and analysis of a proposed fuel system. Fuel 90, 854-864. doi: 10.1016/j.fuel.2010. 09.042

Pearsall, T., and Garabedian, C. (1967). Combustion of Anhydrous Ammonia in Diesel Engines. SAE Technical Paper 670947. doi: 10.4271/670947

Ryu, K., Zacharakis-Jutz, G. E., and Kong, S.-C. (2014a). Effects of gaseous ammonia direct injection on performance characteristics of a sparkignition engine. Appl. Energy 116, 206-215. doi: 10.1016/j.apenergy.2013. 11.067

Ryu, K., Zacharakis-Jutz, G. E., and Kong, S.-C. (2014b). Performance enhancement of ammonia-fueled engine by using dissociation catalyst for hydrogen generation. Int. J. Hydrogen Energy 39, 2390-2398. doi: 10.1016/j.ijhydene.2013.11.098
Sasaki, S., and Sarlashkar, J. (2012). Internal Combustion Engine With Ammonia Fuel. US patent No, 8,166,926B2. Washington, DC: U.S. Patent and Trademark Office.

Sawyer, R., Starkman, E., Muzio, L., and Schmidt, W. (1968). Oxides of Nitrogen in the Combustion Products of an Ammonia Fueled Reciprocating Engine. SAE Technical Paper 680401. doi: 10.4271/680401

Starkman, E., James, G., and Newhall, H. (1967). Ammonia as a Diesel Engine Fuel: Theory and Application. SAE Technical Paper 670946. doi: 10.4271/670946

Starkman, E., Newhall, H., Sutton, R., Maguire, T., Farbar, L. (1966). Ammonia as a Spark Ignition Engine Fuel: Theory and Application. SAE Technical Paper 660155. doi: 10.4271/660155

Susumu, K., Nakamura, N., Shimizu, R., Sugimoto, T., and Kim, K.-O. (2009). Ammonia Burning Internal Combustion Engine. Internation Patent No WO 2010/079846 A1.

Valera-Medina, A., Xiao, H., Owen-Jones, M., David, W. I. F., and Bowen, P. J. (2018). Ammonia for power. Prog. Energy Combust. Sci. 69, 63-102. doi: $10.1016 /$ j.pecs.2018.07.001

Westlye, F. R., Ivarsson, A., and Schramm, J. (2013). Experimental investigation of nitrogen based emissions from an ammonia fueled SI-engine. Fuel 111, 239-247. doi: 10.1016/j.fuel.2013.03.055

Wijayanta, A. T., Oda, T., Purnomo, C. W., Kashiwagi, T., and Aziz, M. (2019). Liquid hydrogen, methylcyclohexane, and ammonia as potential hydrogen storage: comparison review. Int. J. Hydrogen Energy 44, 15026-15044. doi: 10.1016/j.ijhydene.2019.04.112

Woo, Y., Jang, J. Y., Lee, Y. J., and Kim, J. N. (2014). "Recent progress on the ammonia-gasoline and the ammonia-diesel dual fueled internal combustion engines in Korea," in 11th Annual NH3 Fuel Conference (Des Moines, IA).

Zhou, M., Wang, Y., Chu, Y., Tang, Y., Tian, K., Zheng, S., Chen, J., and Wang, Z. (2019). Ammonia as an environmentally benign energy carrier for the fast growth of China. Energy Proc. 158, 4986-4991. doi: 10.1016/j.egypro.2019.01.668

Conflict of Interest: The authors declare that the research was conducted in the absence of any commercial or financial relationships that could be construed as a potential conflict of interest.

Copyright $(02020$ Mounaïm-Rousselle and Brequigny. This is an open-access article distributed under the terms of the Creative Commons Attribution License (CC BY). The use, distribution or reproduction in other forums is permitted, provided the original author(s) and the copyright owner(s) are credited and that the original publication in this journal is cited, in accordance with accepted academic practice. No use, distribution or reproduction is permitted which does not comply with these terms. 